\title{
Indian File: A Miscellany
}

\section{The Term Amerindian}

In 1493 Columbus wrote of the Indios that he met, believing them to be natives of India. Since then the term Indian has been applied to all aborigines of the New World except the Eskimo, who receive a special designation owing to their singular appearance and unusual mode of life. Indian has also been used for the specific term for over 60 native plants and a variety of other New World phenomena.

The recognition that the term Indian without qualification results in confusion with the millions in the Asian subcontinent led to the substitution of American Indian, American Race, American Aborigine and Indigène of America. The term Redskin was originally applied to the painted Beothuks of Newfoundland, and became a misnomer for all aborigines. The term Savage from the French "sauvage" has also been used to classify the natives of the New World.

In 1899 Major J. W. Powell, director of the Bureau of American Ethnology, encouraged the use of the term Amerind, which had been introduced by a lexicographer, as a substitute for the cumbersome American Indian and to resolve the confusion surrounding the use of the term Indian. The variant Amerindian has received some use, but on the whole has failed to displace the ambiguous Indian.

In his Indians of North America (Chicago, Univ. of Chicago Press, 1961, pp. 668) Harold Driver does not use Amerindian, favoring American Indian and Indian, nor is it noted in his extensive bibliography. Likewise it does not occur in Jenness's Indians of Canada (Dept. of Mines, Nat. Mus. Canada, Bull. 65, Anthr. Ser. 15, various editions, 446 pages), although Jenness included sections on the Eskimo, which he classified as distinct from the Indian.

The term Amerindian has much to commend it. Its meaning is readily understood by scientist and layman alike and serves to distinguish between the aborigines of America and the citizens of India. The necessity of such distinction is obvious and should be encouraged. The term Amerind appears to be an unsatisfactory acronym because its meaning is not as readily apparent as Amer- 
indian, because states of the New World refer to their national groups by "ian" or "an" suffixes, and because it seems to reflect an inanimate quality.

Ottawa, Canada

J. A. Rayburn

\section{Alias Pangayo}

Pangayo is given as the alias of Zekiah Swamp, Charles County, Southern Maryland, on Herrman's 1670 map of Maryland (Zachkia Swamp als Pangayo) and on Maryland 1719 Senex (Zachkia swamp als Pangayo). Beginning at an earlier date (1658) it also appears in the Archives of Maryland: (XLI, for 1658) "a Pangayo Indian"; (II, for 1666) "Indians of ... Panyayo," "... great men of Pangayò"; (XV, for 1666) "Indians of ... Pangayo"; and (LI, for 1673-76) "... our mannor of Pangaya," "Pangayah mannor," "... mannor of Pangaya." Much later, in Archives XXXVIII (for 1719) one finds the only appreciable variant: the "reserve of Panguiash Mannor" (Charles County). The latter is indexed as Panguiah Manor, with the sh (Panguiash) evidently taken as an error.

Except for the possibly erroneous Panguiash, the spellings and phraseology are not helpful etymologically. One learns that there were Pangayo Indians; one learns that there was a Pangayo Manor. Principally, however, one learns that Pangayo was the other name of Zekiah Swamp. Dismissing on principle the possibility that Pangayo comes from the name of the "Pangayo Indians," one concludes that Pangayo means something descriptive of a swamp.

The only applicable Algonquian stem that could give Pangayo and that has a meaning suitable for a Southern Maryland swamp is PA *penkwi- "dust, powder, ashes," found in William Strachey's Powhatan vocabulary of 1612 as pungwe "ashes." Related words in Strachey (op.cit.) are pahqwaua "spark," and poengwus "gnat." The name of a Nanticoke emperor and his Indians (Archives, XXIX, XXXV, 1713, 1725), Sam Panquash (Panquass), resembles Strachey's poengwus "gnat"; but the Nanticoke Indian language was probably more similar to Delaware than to Powhatan. However, when one finds Panguiash for Pangayo in Southern Maryland (v. "reserve of Panguiash Mannor," above), it is another matter. 
Though Panguiash could be a scribal error for Panguiah, or even an adjective in English - $i s h$, yet it is close enough to Powhatan to be a cognate of Strachey's poengwus.

If Pangayo is from Powhatan (Strachey) pungwe, or a closely similar Maryland word, an acceptable meaning hinges on several more or less reasonable conjectures. The least reasonable conjecture is that Pangayo means "muddy, miry," which I mention only because one of the cognates (Natick pukquee) means "ashes, mire, mud." More reasonable is the conjecture that the meaning is "dusty," even "sandy" (note Abnaki pégui "sand"); and an extension of this meaning (considering, also, Strachey's poengwus "gnat") is "mosquitoey, gnatty," insofar as a swarm of gnats constitutes a sort of dust or powder. For a final conjecture, perhaps the best, there is the possibility that the land here in Indian times was covered with ashes, because of clearing by burning, or because of a forest fire. Notice Amandus Johnson's similar explanation of Queponco, Worcester County, Maryland (in Peter Lindeström's Geographia Americae with an Account of the Delaware Indians ... [Philadelphia, 1925], p. 334). Queponco, so Johnson thought, was from kuweu-ponka "the pine-wood ashes," a composition of Del. cuwe "pine tree" and ponk "dust, ashes, powder."

H. K.

\section{Earmarks}

Dr. Virgil Vogel has undertaken to assort the more characteristic opening and closing syllables of Eastern Amerindian toponyms. $\mathrm{He}$ concludes: "In the eastern half of the United States and Canada, most aboriginal languages belong to the Algonquian, Iroquoian, Siouan, or Muskhogean stocks. Throughout that area, a place name is likely to be of Indian origin if it begins with chatta or chitta, che, chi or she, ke, kichi or kitchi, maqua, massa, matta, michi, min, minne, missi, mowa, nam or nahm, nipi, sag or saug, sinni, tusca or tusk, $w a b$ or wap, and win. A place name is probably aboriginal also if it ends in ac, ack or ic, ah, akee, aki, aug, auk, aukee, awa, eka or equa, gan, gami, hanna, hanne, hany or heny, in or ing (including Mahoning, Munising and Ossining, but not Flushing or Reading), ink, ish, ka, lusa or loosa, nee, oc, oga, okee, ola, ong, ota, otan, see, 
sha, sippi, uc, uk, ut or et. But bear in mind that beginning syllables especially have often lost an initial sound in white usage; e.g., sinni should be assini or ossini (Alg., "stone, rock"), but seldom appears that way in place names (v. Sinissippi, Sinsinawa). Terminal sounds are also sometimes missing: Chicago should really be Chicagong."

\section{Adena [ədínə]}

It is an interesting coincidence that Adena, the ethnological name of the culture of North America's prehistoric Mound-builders, ${ }^{1}$ can almost as easily be derived from a general Algonquian word for "mountain" (aden, -adina, -atin, -utton, etc.) as from Greek " $\alpha \delta \eta \nu$ "enough, plenty," its correct etymological source. The Algonquian word is found in such place names as Katahdin, Massanutten, and Pasadena. It occurs in the vocabularies as follows: Abenaki aden (Laurent "A mountain"); Ojibwa -adina (Baraga, Pasadina "There is a low place between two mountains," sagadina "There is a group of mountains"); Algonkin -atin (Cuoq "Montee"); Powhatan -utton (Strachey Romutton "Mound"). An Algonquian name for the Mound-builders would be unfitting, of course; the Adena people were not Algonquians.

The Greek origin of Adena was secondary and unintentional. Originally it was the name (Greek " $\alpha \delta \eta v$ "to one's fill" $+-a$ ) of Ohio Governor Thomas Worthington's "lavishly decorated" home Adena or "Paradise," built by Latrobe between 1805 and 1807. As Delf Norona, Director of the Mound Museum, Moundsville, W.Va., puts it (letter, Oct. 1966): “A former governor of Ohio gave his estate that name, and when long years after his death, the particular type mound was excavated by Dr. William Mills [in 1901], on the Governor's estate, he named the mound and the culture by the name of "Adena.", 2

H. K.

1 Adena is also the name of a mound (the Adena Mound, near Chillicothe), a people (the Adena people), a pipe (the Adena pipe), and a town (Adena, Jefferson Co., Ohio).

2 Webster's Third New International Dictionary, unabridged (Springfield, 1966) mistakenly attributes the adjective Adena (of "Adena culture," "Adena people," etc.) to the name of the town (Adena), which it calls "its type station." 


\section{News from Mexico}

Dr. Gutierre Tibón, of Mexico City, author of a comparative etymological dictionary of personal names, reviewed in this journal by Jack Dabbs in 1956 (Names, 4: 4, 245-46), informs us that the first volume of his projected Enciclopedia de Mexico will bave "American Indian etymologies of Mexican place names - something new in this kind of book; also etymologies of personal names which became place names, like Abasolo, Hidalgo, Allende, etc." In addition he states: "My book on the etymology of Mexico (400 pages) will come out in 1967."

\section{News from Washington}

Through the courtesy of one of its coauthors, Dr. D. J. Orth, of the U.S. Geological Survey, we are in receipt of Delaware Place Names, Geological Survey Bulletin 1245 (Washington, 1966. Pp. 124). This work is a gazetteer of the known places and features of Delaware, and includes "some information on name derivation." However, the Introduction remarks, "No attempt has been made to do any original name study." Each of the states whose place names have been relatively neglected (e.g., Florida, Mississippi, Tennessee, Utah) should have a preliminary study such as this. Perhaps its greatest merit is the fact that "All known variant names and spellings are listed alphabetically." This is a boon for the place name etymologist, for whom the amassment of variant spellings may well be half the job.

Dr. Orth speaks (letter, April, 1967) of proofreading the government's 1200 page "Alaska Dictionary," and has sent the present writer two unedited page proofs. He remarks that the volume will contain several thousand "native names," and that its purpose is twofold: (1) to catalog all known geographic names in the state of Alaska; and (2) "to report all known information in our files and records concerning the origin and meaning of each name." Some of the names and meanings reported are the result of field work by Dr. Orth himself. This dictionary, with its approximately 45,000 entries, forms the best possible basis for an etymological study of the toponymy of our new state. But the enormity of the task is somewhat appalling. 


\section{The Potomac Debate}

Mr. Charles Edgar Gilliam, of Petersburg, Va., expresses dissatisfaction with the conclusion that Potomac means "place of trade," or "emporium," especially if the idea of trade in buffalo skins or steatite is involved.

He declares (letter, September, 1966): "Incidentally, all ideas of buffalo hide trade at Patawomeck prior to 1670 , or later, have been exploded. There is no Virginia narrative evidence of trade in steatite. Their principal local Indian trade was antimony, powdered and sold in sacks for warriors to sprinkle on greased bodies and make them sparkle as with myriad tiny lights in the sun. The principal trade with the early colonists was corn and the fur of local fauna, at least down to 1623-24. Virginia narratives mention only two buffalo robes owned by any chief. Powhatan gave one to King James and it is still in the Ashmolean collection, Oxford. ${ }^{4}$

"When interpretations of Patawomeck began there were emphatic climates of opinion permeating Indian trade carrying the buffalo hide theme from west of the Mississippi all over the East. There is abundance of evidence collected by cultural psychologists (anthropologists) that when such climates prevail, they unconsciously affect the best scientists, and scholars."

4 No doubt many American visitors to Oxford have seen this relic, which hangs in a glass case on one of the walls of the Ashmolean Museum. It is my recollection that it is a deerskin. H. $\mathrm{K}$. 